\title{
India travels and transitioning Luxembourg Appropriate thresholds and scales of change
}

This is a new year's letter written by the founder of the Centre for Ecological Learning Luxembourg (CELL) to the executive board on the occasion of a journey to India. CELL is an independent, volunteer-led grassroots nonprofit organization founded in 2010 and based in Beckerich. CELL's scope of action is the Greater Region of Luxembourg, hence its mode of operating through decentralized action groups in order to establish and maintain community gardens, food co-ops, and other social-ecological projects in different parts of Luxembourg. CELL also develops and organizes various courses, provides consultancy services for ecological living, participates in relevant civil society campaigns, and does some practical research on low-impact living. The broad objective of CELL is to provide an experimental space for thinking, researching, disseminating, and practicing lifestyles with a low impact on the environment, and learning the skills for creating resilient postcarbon communities. CELL is inspired by the work of the permaculture and Transition Towns social movements in its aims to relocalize culture and economy and, in that creative process, improve resilience to the consequences of peak oil and climate change.

Permaculture is an ecological design system developed in the 1970s in Australia for sustainability in all aspects of human endeavor. Permaculture integrates land, resources, people, and the environment through mutually beneficial synergies - imitating the no-waste, closed-loop systems seen in diverse natural systems. Permaculture studies and applies holistic solutions that are applicable in rural and urban contexts at any scale. It is a multidisciplinary toolbox including agriculture, water harvesting and hydrology, energy, natural building, forestry, waste management, animal systems, aquaculture, appropriate technology, economics, and community development.

The Transition Towns concept emerged from work that permaculture designer Rob Hopkins had done with the students of Kinsale Further Education College in writing an "Energy Descent Action Plan." This looked at across-the-board creative adaptations in the realms of energy production, health, education, economy, and agriculture as a "road map" to a sustain- 
able future for the town of Kinsale. Two of his students, Louise Rooney and Catherine Dunne, set about developing the Transition Towns concept and took the far-reaching step of presenting it to the Kinsale Town Council, resulting in the historic decision by councillors to adopt the plan and work toward energy independence. The idea spread virally, giving rise to hundreds of towns worldwide that are working on the transition toward a low-carbon future.

\section{Dear friends,}

Khalil Gibran has perhaps said it best: "For that which you love most in him may be clearer in his absence, as the mountain to the climber is clearer from the plain" (Gibran, 1923/2002). Gibran was speaking about a friend. However, one can effortlessly apply this adage to a place also. I have had the privilege to journey to India over the past weeks to my friends' wedding. Through this opportunity I was given the leisure to visit several places in this vast and incredibly diverse country, encounter and speak with some people there, and grasp the occasion to learn from texts and immediate experience about the ways in which people relate to their environment there. Looking at the mountain from the plain, I have been able to reflect on the efforts of Luxembourgish civil society but setting it within a wider context that, in our busy actionists', permaculture designers', and community organizers' lives, sometimes does fade out of view. Indeed, when one is focusing, as our organization's work does, on Luxembourg's issues of resilience, the risk is that one disregards the ways in which our Western European habit of living beyond our environmental means consequently displaces the environmental and social impact into faraway places that are seemingly unconnected to our lives and ways of thinking. We may get caught up in political skirmishes in teacups over community gardening, we may fall into event organization mode (which may be pleasant to all involved but could be construed as lacking efficiency), we may happily be designing permaculture gardens and implementing designs on small scales, and before long, we may lose sight of the larger picture. The latter may be brought home to us in some campaigns we have been supporting, but the experiential focus of our organization must be revisited from time to time in order to avoid working in an insular fashion. The ways in which to achieve resilience may be specific to the local context, but lessons are to be learned from other places that face other kinds of issues, and that may work according to entirely different blueprints and processes.

To help us think through this, I would like to focus on two teachings from my journey. One concerns women, the other water-both absolutely vital for the health of our ecosystems and communities. The teachings are about the relevant thresholds and scales of change. The impressions 
that remain with me from my rather brief sojourn in this rapid-growth emerging economy concern the traffic, a seemingly endless and chaotic outpour of motorized vehicles carrying people across streets that were not designed to welcome this quantity of wheels. Every place seems to be crowded and noisy, with a million deities and humans comingling. I also mourned at the sight of pervasive ecological catastrophe: the stench of latrine water lagoons, the strange absence of birdlife and wildlife more generally, the news of several elephants being run over by a train, the alltoo apparent inequalities between people in a hierarchical society on their way to a consumerist society, the realization that here, food security is a bigger urban issue than I would have believed from my (partisan and partial) reading of the organization Navdanya, headed by Vandana Shiva.

On 29 December 2012, as I was traveling in India, Nirbhaya (pseudonym), a 23-year-old woman, died in a Singapore hospital from the injuries inflicted, about a week earlier, by an atrociously brutal collective sexual assault on a Delhi bus (see Burke 2013). This crime led to countrywide demonstrations and subsequently got wide coverage in the media both in India and globally. Along with India's middle class, within which this brutal crime was perpetrated, my anger and grief were provoked by the way in which women face heavy discrimination from men in India today. However, I hope that the public demonstrations and the plea to bring the perpetrators to justice swiftly will lead to concrete action and change, both on the legislative level as well as on the level of people's and institutional attitudes and action.

The case helped me think through thresholds of relevant action, and the ways in which one moment can change the course of action of a people, as they were galvanized to take democratic action, as the proverbial drop brought the vessel to overflow. In Luxembourg, I hope that no catastrophe will have to occur in terms of the multiple crises we face in order for the path of change to become a reality. It is, however, my fear that true and lasting change needs to be triggered by an event of some magnitude. In this sense, the courses and events we are organizing within CELL may sometimes follow an "event organization" culture, but if the social fabric we manage to make salient during these events and times spent together is solid and inspirational, I strongly believe that the change will carry across into people's personal lives, which has been one of our explicit aims since the founding of the organization, and into public policy, which has been apparent with regard to the case of the Luxembourg city community garden.

The second teaching from India concerns the way in which the rush for dwindling resources, above all water, within a capitalist framework that is geared toward economic growth and "development" without an 
explicit, coherent framework of governance at the national and regional levels must, in the long term, lead to negative environmental impacts and unequal access to resources. Worldwide, agriculture accounts for $70 \%$ of all water consumption (see, e.g., FAO Report, 2003). Water is a precious resource, the availability of which is greatly affected by climate change. India, just like other countries in Southeast Asia, is projected to experience warming above the global average, along with increased seasonal variation in temperature and heightened variability in monsoon precipitation. This will have drastic effects on Indian agriculture, both on subsistence agriculture and on productivity of large-scale agriculture. It is a variation on the usual modernizing story of agriculture under the pull of consumerism. In India, agriculture faces a plethora of issues: farmers' suicides continue to increase in some states, as growth rates in yield are declining. Farming is fast becoming a nonviable economic activity, with high price volatility as domestic agriculture has been exposed to international competition. Land degradation in the form of depletion of soil fertility, erosion, and water logging has increased, while the surface irrigation expansion rate and the level of groundwater table have decreased. Regional productivity disparities have increased between rain-fed and irrigated areas. It is clear that CELL cannot solve India's problems. To assume that this is our responsibility is an inappropriate assumption of omnipotence and a strange expression of postcolonial inequalities. Although tourism does exacerbate water scarcity, it contributes to uneven development of a specific region and potentially creates new relations of exploitation among locals.

Thinking about this, however, led me to question our idea of scale. Even as I was reading policy reports and commentaries my head got dizzy from the implications. Having been trained as a scientist, I desperately want to believe in the power of generalization and "scaling up." However, I think that the relevant scales for regenerating our earth and our resources must start at the local level. As long as people do not feel that the local level is their own in terms of environmental awareness, which I believe was the case in those parts of India I visited, they will not care enough about it to keep it clean. Of course, if their environment makes them suffer from various water-borne or respiratory diseases from the pollution of air and water, they may not recognize this as a consequence of myriad factors having coincided, such as lifestyle changes, industrial growth, climate change, and so forth. With farmer-poet Wendell Berry, I believe that

[t]here is, as maybe we have all noticed, a conspicuous shortage of largescale corrections for problems that have large-scale causes. Our damages to watersheds[, food systems] and ecosystems will have to be corrected one farm, one forest, one acre at a time. (Berry 2005) 
And it is on this level that CELL would like to keep operating.

I am looking forward to a year full of regenerational activities for our earth and our social fabric.

Metta to all of you and see you soon,

Katy Fox

KATY FOX is a social anthropologist passionate about social and cultural transformation. Her doctoral research concerned itself with the impacts of EU agriculture policy on the lives of subsistence farmers in Romania (2006-2010). Her follow-up research in Romania (2009) brought to the fore environmental questions and she has since worked with permaculturists and movements defending the right to a livelihood for small farmers. While her earlier interests had a strong focus on the economy and power, her current work is more focused on deliberative paths for desired social change and the interconnections between ecosystems and social systems. In 2010, she moved back to her native Luxembourg (Beckerich) and founded CELL, the Centre for Ecological Learning Luxembourg, a laboratory for the energy transition and permaculture ethics and practice in relation to peak oil and climate change concerns. She situates her thoroughly interdisciplinary work somewhere between systems theory, ecology, political economy, social science, permaculture design, art, and radical pedagogy. She is particularly interested in putting resilience research into practice, participatory workshops, and imaginative methods for bringing about change, and is currently acquiring more knowledge about plant ecology and gardening.

\section{REFERENCES}

Berry, W. (2005). The way of ignorance and other essays. Washington, DC: Shoemaker \& Hoard.

Burke, Jason (2013) Delhi Gang Rape Trial Begins The Guardian, web edition 21.01.2013. Retrieved from http://www.guardian.co.uk/world/2013/jan/21/ delhi-gang-rape-trial-begins

FAO Report. (2003). Agriculture, food and water. Retrieved from ftp://ftp.fao.org/ agl/aglw/docs/agricfoodwater.pdf

Gibran, K. (2002). The prophet. London: Penguin. (Original work published 1923)

\section{WEBSITES}

Centre for Ecological Learning Luxembourg (CELL), http://www.cell.lu/

Navdanya Network, http://www.navdanya.org/

Transition Town Network, http://www.transitionnetwork.org/

Permaculture Research Institute Australia, http://permaculturenews.org/ 